\title{
Estimation of Renin Activity in Human Amniotic Fluid of Normal and Toxemic Pregnant Women
}

\author{
Masaru Maebashi and Kaoru Yoshinaga \\ The Second Department of Internal Medicine (Prof. T. Torikai), \\ Tohoku University School of Medicine, Sendai
}

\begin{abstract}
High concentrations of pressor enzyme have been found in amniotic fluid collected from normal and toxemic pregnant women at delivery. The enzyme activity was significantly increased in toxemia as compared with that in normal pregnancy.

Physico- and pharmaco-chemically this pressor enzyme was similar to human renin and its reaction product with human plasma was similar to angiotensin. Probable sources of amniotic renin were discussed.
\end{abstract}

Activation of the renin-angiotensin system in toxemic pregnancy raised the question as to whether renin originates from impaired maternal kidney or from pathological placenta. ${ }^{2}$ Some investigators ${ }^{3-10}$ demonstrated renin or renin-like enzyme in placental and uterine tissue. Other workers ${ }^{11}$ reported on the presence of high concentration of renin in human amniotic fluid. However, there has been no information on renin content in amniotic fluid of toxemia. If higher concentration of renin is found in amniotic fluid in toxemic pregnancy than that in normal pregnancy, this would afford a clue for explanation about the site of renin production in toxemia.

The present study was designed to determine the renin activity of amniotic fluid in normal and toxemic pregnancies and what relationship, if any, exists between plasma and amniotic renin activity.

\section{Materials and Methods}

Samples of amniotic fluid were obtained from 34 pregnant women, 23 normal and 11 toxemic gravids at the time of labor. None of the normal pregnant women showed any clinical abnormality to term. All of the toxemic patients, who had hypertension, proteinuria and edema, were diagnosed by the criteria of the American Committee on Maternal Welfare.

Thirty samples were collected after spontaneous rupture of the fetal membranes. In the remaining 4 cases of severe toxemic pregnancy the sumples were taken at Cesarean section. The fluid was centrifuged immediately after sampling at room temperature and the supernatant was used for the experiment.

Five $\mathrm{ml}$ of amniotic fluid were added to $10 \mathrm{ml}$ of human plasma adjusted to $\mathrm{pH} 5.5$. Another $10 \mathrm{ml}$ aliquot of the same plasma as used above was treated as a blank, in which $5 \mathrm{ml}$ of physiological saline were added instead of amniotic fluid. Then the mixture was

Received for publication, August 23, 1968. 
incubated at $37^{\circ} \mathrm{C}$ for 2 hours. Further procedures in this experiment were the same as those used by us for estimation of plasma renin activity ${ }^{12}$ and renin substrate. ${ }^{13}$ Human plasma was obtained from healthy volunteers.

The enzyme activity in amniotic fluid was expressed in terms of angiotensin formed by the enzyme during the incubation, the values being calculated by subtracting the blank estimations from those of the amniotic fluid samples. In the majority of blanks, however, pressor activity was negligible as compared with that of amniotic fluid sample.

\section{Results}

\section{Presence of renin in amniotic fluid}

The injection of amniotic fluid alone into rats had no effect on blood pressure. Similarly no change was observed with the fluid which was incubated at $\mathrm{pH} 5.5$ and $37^{\circ} \mathrm{C}$ for 2 hours. However, when amniotic fluid was incubated with human plasma, it led to the production of a strong pressor substance, the maximum activity of which was obtained at pH 5.5. This reaction product was extractable by our procedures ${ }^{12}$ used for isolation of angiotensin. The active substance in amniotic fluid was compared with human renin ${ }^{13}$ obtained from the kidney. Both were heat-labile and non-dialysable through cellophane membranes. Furthermore, both substances had the same optimal $\mathrm{pH}$ range and temperature when incubated with human plasma. The reaction product elicited a pressor response in rats similar to that by synthetic angiotensin II and angiotensin formed from human renin and plasma. These substances were similarly heat-stable, dialyzable and rapidly destroyed by trypsin and chymotrypsin. From these results it was concluded that the active principle in amniotic fluid was renin and that the reaction product was angiotensin.

\section{Absence of angiotensinase in amniotic fluid}

To exclude the presence of angiotensinase in amniotic fluid, synthetic angiotensin was incubated with the fluid as follows: To $5 \mathrm{ml}$ of the fluid, $3 \mathrm{ml}$ of angiotensin solution in physiological saline $(20 \mathrm{ng} / \mathrm{ml})$ were added, and the mixture was incubated at $37^{\circ} \mathrm{C}$ for 2 hours. After the incubation, the sample was treated according to our method reported previously. The recovery of the angiotensin added to the fluid was assayed biologically. As shown in Table 1, no decrease in pressor activity was observed. Thus, the amniotic fluid was proved to be

TABLE 1. Recovery of synthetic angiotensin $I I$ added to $5 \mathrm{ml}$ of amniotic fluid

\begin{tabular}{c|c|c|c}
\hline $\begin{array}{c}\text { Incubation } \\
\text { time } \\
(\mathrm{min})\end{array}$ & $\begin{array}{c}\text { Added dose of } \\
\text { angiotensin } \\
\text { (ng) }\end{array}$ & $\begin{array}{c}\text { Estimated value } \\
\text { of angiotensin } \\
\text { (ng) }\end{array}$ & $\begin{array}{c}\text { Recovery rate } \\
(\%)\end{array}$ \\
\hline 0 & 60.0 & 59.0 & 98.3 \\
30 & 60.0 & 61.5 & 100.2 \\
60 & 60.0 & 61.4 & 100.2 \\
120 & 60.0 & 61.6 & 100.3 \\
180 & 60.0 & 60.0 & 100.0 \\
\hline
\end{tabular}




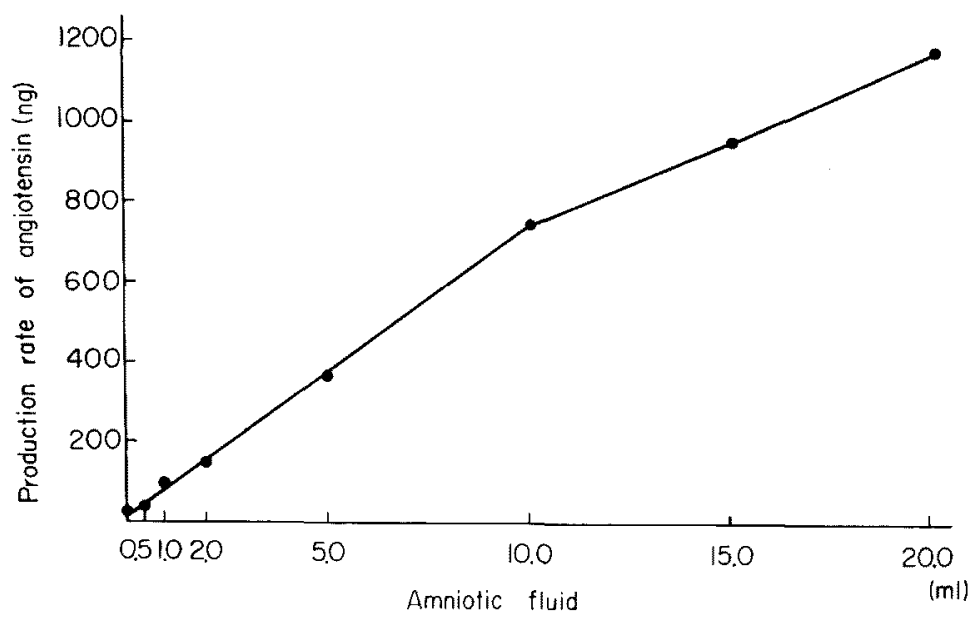

Fig. 1. The production rates of angiotensin by the incubation of $10 \mathrm{ml}$ of plasma with various amounts of amniotic fluid.

angiotensinase-free.

\section{Doses of amniotic fluid}

The rate of angiotensin formation by incubating $10 \mathrm{ml}$ of human plasma and various amounts of amniotic fluid from 0.5 to $20 \mathrm{ml}$ was examined. The plasma used here was obtained from several volunteers, and the mixture of plasma and amniotic fluid was divided into $10 \mathrm{ml}$ aliquots. The results are illustrated in Fig. 1, in which it can be seen that the rate of angiotensin production is dependent on and proportionate to the amount of added amniotic fluid. From these results, the finally decided condition for estimation of amniotic renin activity was to incubate one volume of amniotic fluid with two volumes of human plasma.

Assay of renin activity in amniotic fluid

Fig. 2 shows the results on renin activity in amniotic fluid from normal and toxemic pregnant women. In normal pregnancy the activity ranged from 60 to 300

Renin activity in amniotic fluid

(ng equiv. to angiotensin $\mathrm{II} / 10 \mathrm{ml}$ of amniotic fluid)

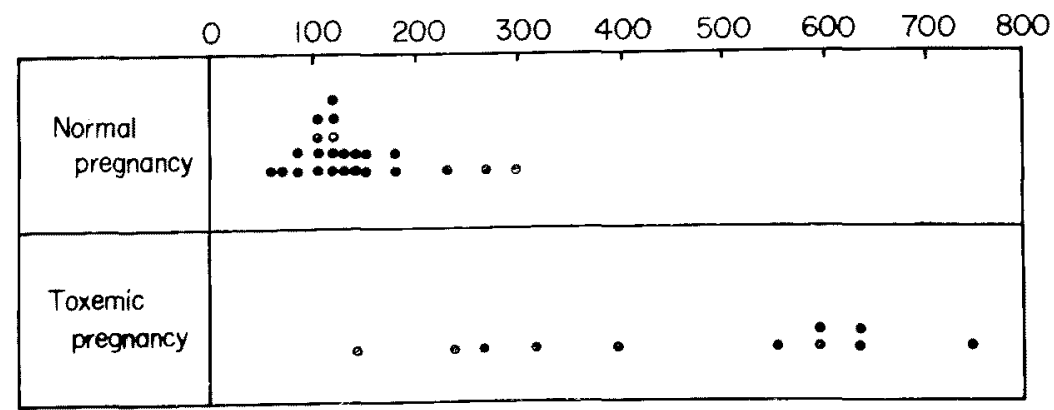

Fig. 2. Renin activity in amniotic fluid of normal gravids and toxemic pregnant women. 
ng equivalent to synthetic angiotensin II per $10 \mathrm{ml}$ of amniotic fluid with a mean of $138 \mathrm{ng}$. In toxemic pregnancy amniotic renin activity was more elevated than that in normal pregnancy, ranging from 144 to $750 \mathrm{ng}$ with a mean of $470 \mathrm{ng}$.

\section{DisCUSSION}

It is evident from the present findings that amniotic fluid contains a large amount of pressor enzyme, the properties of which are similar to those of renin. This enzyme in amniotic fluid reacted with human plasma to produce a vasoconstrictive substance comparable to angiotensin. However, there was no substrate of the enzyme in amniotic fluid. Gomel and Hardwick ${ }^{14}$ failed to detect a pressor substance in amniotic fluid in toxemic pregnancy. On the contrary, the present experiments demonstrate that amniotic renin activity was highly increased in toxemic pregnancy in comparison with that in normal pregnancy. This discrepancy could be possibly attributed to that the above authors did not take the substrate into consideration in their experiments.

The origin of this pressor enzyme in amniotic fluid has not been investigated in the present study. Many articles ${ }^{3-10,14-19}$ on the origin of enzymes in amniotic fluid have shown two possibilities; one is that the enzyme in the fluid is derived from intrauterine tissue, and the other from maternal kidney $A$ third hypothesis has been offered by Brown and his associates, ${ }^{11}$ who suggested the fetal urine as a possible source of amniotic renin. Electrophoretic, ${ }^{15}$ immunological $^{16,17}$ or radioisotopical ${ }^{18}$ techniques presented evidence for the presence of maternal serum protein in amniotic fluid. This finding may suggest the possibility that the enzyme passes the placental barrier from maternal plasma to amniotic fluid, where it is stored against concentration gradient especially in toxemic pregnancy. Absence of substrate in amniotic fluid might be due to the selective protein transport of the placenta.

In favor of the second possibility that renin in amniotic fluid originates from intrauterine tissues, Hunter and Howard ${ }^{3}$ found a vasopressor substance, named 'histerotonin', in placental extract from toxemic patients. Other investigators demonstrated the presence of renin-like substance in the cat's placenta, ${ }^{4}$ and in the pregnant uterus and placenta of the pig. ${ }^{5}$ Gross and his co-workers ${ }^{6.8}$ obtained a similar finding in the rabbit. Furthermore, they reported that the enzyme isolated from placental extract was identical with renin. These observations suggest that the enzyme is produced from intrauterine tissues, transferred to amniotic fluid and stored there. This extrarenal origin of renin in amniotic fluid would explain the difference in concentration between amniotic fluid and maternal blood, because placental barrier impedes the transfer of the enzyme from amniotic fluid to maternal circulation. Berger and his collaborators ${ }^{19}$ showed that the production of placental ischemia in the rabbit caused a symptom-complex like toxemia of pregnancy, which was interpreted in connection with liberation of a pressor substance into the maternal circulation. Therefore, it is supposed that in toxemic pregnancy high concentration of renin produced in uterine tissues, 
perhaps in response to anoxia of the placenta, may enter not only into amniotic fluid but also into the maternal circulation and elevate the enzyme level in both amniotic fluid and maternal plasma. Consistent with this concept are the earlier reports $^{1,2}$ that plasma renin activity was increased in toxemic pregnancy, though at that time renal damage due to toxemia was considered to be a primary cause of increased renin activity. Dual origin, uterine and renal, though probable in this condition, is still to be confirmed.

\section{Acknowledgment}

We thank to Prof. T. Torikai for his kind advice in this study and to Dr. J. Sekiguchi, Department of Gynceology at Takada National Hospital, for his courtesy to allow us to collect amniotic fluid.

\section{References}

1) Maebashi, M. Estimation of circulating renin under various clinical conditions. Jap. Circulat. J., 1964, 28, 778-785.

2) Cession, G. Dosage de la rénine plasmatique dans la gestation. C.R.Soc. Biol. (Paris), $1966,160,1120-1123$.

3) Hunter, C.A., Jr. \& Howard, W.F. A pressor substance (hysterotonin) occurring in toxemia. Amer. J. Obstet. Gynec., 1960, 79, 838-846.

4) Stakeman, G. A renin-like pressor substance found in the placenta of the cat. Acta path. microbiol. scand., 1960, 50, 350-354.

5) Gould, A.B., Skeggs, L.T. \& Kahn, J.R. The presence of renin activity in blood vessel walls. J. exp. Med., 1964, 119, 389-399.

6) Gross, F., Schaechtelin, G., Ziegler, M. \& Berger, M. A renin-like substance in the placenta and uterus of the rabbit. Lancet, 1964, 1, 914-916.

7) Bing, J. \& Faarup, P. A qualitative and quantitative study of renin in the different layers of the rabbit uterus. Acta path. microbiol. scand., 1966, 67, 169-179.

8) Ziegler, M. Riniker, B. \& Gross, F. Nature of the pressor substance in rabbit placenta. Biochem. J., 1967, 102, 28-32.

9) Gorden, P., Ferris, T.F. \& Mulrow, P.J. Rabbit uterus as a possible site of renin synthesis. Amer. J. Physiol., 1967, 212, 703-706.

10) Capelli, J. P., Wesson, L.G., Aponte, G. E., Jaffe, E. \& Faraldo, C. Renin activity in anephric subjects. J. clin. Invest., 1967, 46, 1042 (abstract).

11) Brown, J.J., Davies, D.L., Doak, P.B., Lever, A.F., Robertson, J.I.S. \& Tree, M. The presence of renin in human amniotic fluid. Lancet, 1964, 2, 64-66.

12) Yoshinaga, K., Aida, M., Maebashi, M., Sato, T., Abe, K. \& Miwa, I. Assay of renin in peripheral blood. A modification of Helmer's method for the estimation of circulating renin. Tohoku J. exp. Med., 1963, 80, 32-41.

13) Maebashi, M., Yoshinaga, K., Aida, M., Okuyama, M. \& Oikawa, A. Assay of plasma renin substrate in man. Tohoku J. exp. Med., 1965, 85, 299-304.

14) Gomel, V. \& Hardwick, D.F. Search for a pressor substance in toxemia of pregnancy. Amer. J. Obstet. Gynec., 1966, 94, 308-309.

15) Abbas, T.M. \& Tovey, J.E. Proteins of the liquor amnii. Brit. med. J., 1960, 1, $476-479$.

16) Ruoslahit, E., Tallberg, Th. \& Seppälä, M. Origin of proteins in amniotic fluid. Nature (Lond.), 1966, 212, 841.

17) Usategui-Gomez, M. \& Morgan, D.F. Maternal origin of the group specific (Ge) proteins in amniotic fluid. Nature (Lond.), 1966, 122, 1600-1601.

18) Bangham, D.R. The transmission of homologous serum proteins to the foetus and to 
the amniotic fluid in the rhesus monkey. J. Physiol. (Lond.), 1960, 153, 265-289.

19) Berger, M. \& Boncek, R.J. Irreversible uterine and renal changes induced by placental ischemia (rabbit). Amer. J. Obstet. Gynoc., 1964, 89, 230-240. 